\title{
Pusat Riset Pesantren
}

\author{
Oleh: Aji Sofanudin
}

Tribun, 4 Agustus 2021

Published: https://jateng.tribunnews.com/2021/08/04/opini-dr-aji-sofanudin-pusat-risetpesantren

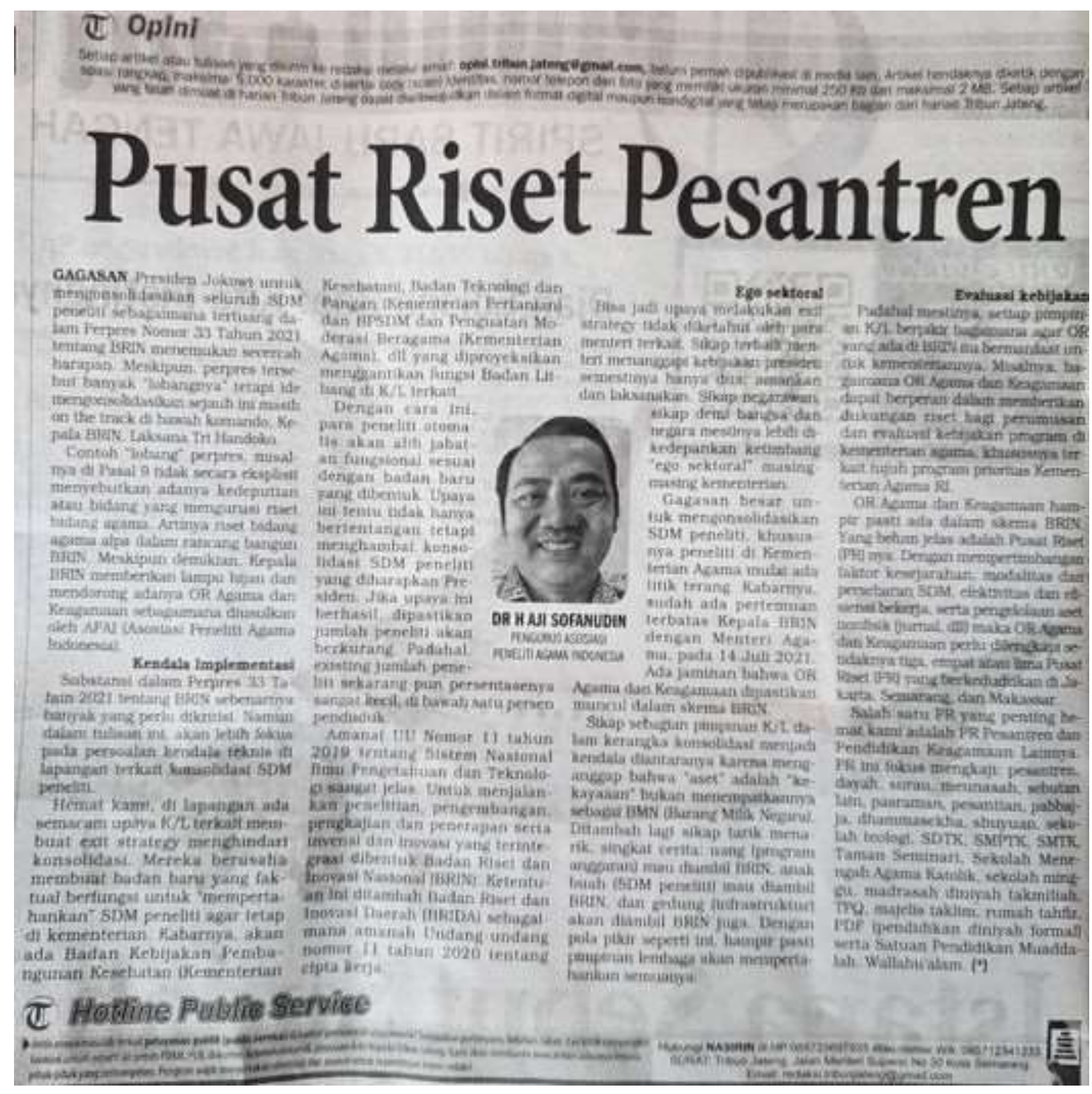




\section{PUSAT RISET PESANTREN}

Oleh Aji Sofanudin

GAGASAN Presiden Jokowi untuk mengonsolidasikan seluruh SDM peneliti sebagaimana tertuang dalam Perpres Nomor 33 Tahun 2021 tentang BRIN menemukan secercah harapan. Meskipun, perpres tersebut banyak "lobangnya" tetapi ide mengonsolidasikan sejauh ini masih on the track di bawah komando, Kepala BRIN, Laksana Tri Handoko.

Contoh "lobang" perpres, misalnya di Pasal 9 tidak secara eksplisit menyebutkan adanya kedeputian atau bidang yang mengurusi riset bidang agama. Artinya riset bidang agama alpa dalam rancang bangun BRIN. Meskipun demikian, Kepala BRIN memberikan lampu hijau dan mendorong adanya OR Agama dan Keagamaan sebagaimana diusulkan oleh APAI (Asosiasi Peneliti Agama Indonesia).

\section{Kendala Implementasi}

Substansi dalam Perpres 33 Tahun 2021 tentang BRIN sebenarnya banyak yang perlu dikritisi. Namun dalam tulisan ini, akan lebih fokus pada persoalan kendala teknis di lapangan terkait konsolidasi SDM peneliti.

Hemat kami, di lapangan ada semacam upaya K/L terkait membuat exit strategy menghindari konsolidasi. Mereka berusaha membuat badan baru yang faktual berfungsi untuk "mempertahankan" SDM peneliti agar tetap di kementerian. Kabarnya, akan ada Badan Kebijakan Pembangunan Kesehatan (Kementerian Kesehatan), Badan Teknologi dan Pangan (Kementerian Pertanian) dan BPSDM dan Penguatan Moderasi Beragama (Kementerian Agama), dll yang diproyeksikan menggantikan fungsi Badan Litbang di K/L terkait.

Dengan cara ini, para peneliti otomatis akan alih jabatan fungsional sesuai dengan badan baru yang dibentuk. Upaya ini tentu tidak hanya bertentangan tetapi menghambat konsolidasi SDM peneliti yang diharapkan Presiden. Jika upaya ini berhasil, dipastikan jumlah peneliti akan berkurang. Padahal, existing jumlah peneliti sekarang pun persentasenya sangat kecil, di bawah satu persen penduduk. 
Amanat UU Nomor 11 tahun 2019 tentang Sistem Nasional IImu Pengetahuan dan Teknologi sangat jelas. Untuk menjalankan penelitian, pengembangan, pengkajian dan penerapan serta invensi dan inovasi yang terintegrasi dibentuk Badan Riset dan Inovasi Nasional (BRIN). Ketentuan ini ditambah Badan Riset dan Inovasi Daerah (BRIDA) sebagaimana amanah Undang-undang nomor 11 tahun 2020 tentang cipta kerja.

\section{Ego sektoral}

Bisa jadi upaya melakukan exit strategy tidak diketahui oleh para menteri terkait. Sikap terbaik menteri menanggapi kebijakan presiden semestinya hanya dua: amankan dan laksanakan. Sikap negarawan, sikap demi bangsa dan negara mestinya lebih dikedepankan ketimbang "ego sektoral" masing-masing kementerian.

Gagasan besar untuk mengonsolidasikan SDM peneliti, khususnya peneliti di Kementerian Agama mulai ada titik terang. Kabarnya, sudah ada pertemuan terbatas Kepala BRIN dengan Menteri Agama, pada 14 Juli 2021. Ada jaminan bahwa OR Agama dan Keagamaan dipastikan muncul dalam skema BRIN.

Sikap sebagian pimpinan $\mathrm{K} / \mathrm{L}$ dalam kerangka konsolidasi menjadi kendala diantaranya karena menganggap bahwa "aset" adalah "kekayaaan" bukan menempatkannya sebagai BMN (Barang Milik Negara). Ditambah lagi sikap tarik menarik, singkat cerita: uang (program anggaran) mau diambil BRIN, anak buah (SDM peneliti) mau diambil BRIN, dan gedung (infrastruktur) akan diambil BRIN juga. Dengan pola pikir seperti ini, hampir pasti pimpinan lembaga akan mempertahankan semuanya.

\section{Evaluasi kebijakan}

Padahal mestinya, setiap pimpinan K/L berpikir bagaimana agar OR yang ada di BRIN itu bermanfaat untuk kementeriannya. Misalnya, bagaimana OR Agama dan Keagamaan dapat berperan dalam memberikan dukungan riset bagi perumusan dan evaluasi kebijakan program di kementerian agama, khususnya terkait tujuh program prioritas Kementerian Agama RI.

OR Agama dan Keagamaan hampir pasti ada dalam skema BRIN. Yang belum jelas adalah Pusat Riset (PR) nya. Dengan mempertimbangan faktor kesejarahan, modalitas dan persebaran SDM, efektivitas dan efisiensi bekerja, serta pengelolaan aset nonfisik (jurnal, dII) maka OR 
Agama dan Keagamaan perlu dilengkapi setidaknya tiga, empat atau lima Pusat Riset (PR) yang berkedudukan di Jakarta, Semarang, dan Makassar.

Salah satu PR yang penting hemat kami adalah PR Pesantren dan Pendidikan Keagamaan Lainnya. PR ini fokus mengkaji: pesantren, dayah, surau, meunasah, sebutan lain, pasraman, pesantian, pabbajja, dhammasekha, shuyuan, sekolah teologi, SDTK, SMPTK, SMTK, Taman Seminari, Sekolah Menengah Agama Katolik, sekolah minggu, madrasah diniyah takmiliah, TPQ, majelis taklim, rumah tahfiz, PDF (pendidikan diniyah formal) serta Satuan Pendidikan Muaddalah. Wallahu'alam.

Tribun Jateng, 4 Agustus 2021

Dr Aji Sofanudin

Pengurus Asosiasi Peneliti Agama Indonesia 